\title{
Variations in standing stocks of central California macrophytes from a rocky intertidal habitat before and during the 1982-1983 El Niño
}

\author{
Steven N. Murray, Michael H. Horn \\ Department of Biological Science, California State University, Fullerton, California 92634, USA \\ and \\ Ocean Studies Institute, Long Beach, California 90840, USA
}

\begin{abstract}
Intertidal macrophytes inhabiting a central California site near Point Piedras Blancas were investigated before and during the extreme 1982-1983 El Niño/Southern Oscillation (ENSO). In contrast to its effects on South American intertidal systems, the 1982-1983 ENSO did not dramatically or immediately affect these central California macrophyte populations. Observed variations from preENSO patterns in total macrophyte abundance and diversity were few and mostly limited to the lateENSO winter (December 1983); values for the ENSO summer (August 1983) were not significantly different from those obtained for 2 previous non-ENSO summers at high-, mid-and low-intertidal levels. At the population level, increases in cover of crustose coralline algae and decreases in fleshy red algae, such as the erect phase of Mastocarpus papillatus, were more extreme during the late ENSO winter. Multivariate analyses distinguished December 1983 from the other winter periods at all 3 intertidal levels, but August 1983 could not be discriminated from pre-ENSO summers
\end{abstract}

\section{INTRODUCTION}

During 1982-1983, California waters were altered by what has been regarded (Barber \& Chávez 1983, Cane 1983, Halpern et al. 1983, Rasmusson \& Wallace 1983, Norton et al. 1985) as the strongest El Niño/Southern Oscillation (ENSO) ocean-atmosphere event of the twentieth century. During this period, coastal waters experienced anomalously high sea surface temperatures (SSTs), low nutrient content (Simpson 1983, 1984, Fiedler 1984, Norton et al. 1985), depression of the thermocline, unusually high sea levels (Simpson 1983, 1984, Norton et al. 1985), extraordinary climatic anomalies (Quiroz 1983) and large wave events (Seymour et al. 1984).

The 1982-1983 ENSO had severe biological consequences in the eastern tropical Pacific, including decreased abundances and productivity of phytoplankton, reduced growth and reproduction of anchoveta, bleaching and increased mortality of reef-building corals, altered abundances of intertidal seaweed and invertebrate populations, and increased mortality and reproductive failure in various sea birds, marine iguanas and marine mammals (e.g. Barber \& Chávez
1983, 1986, Feldman et al. 1984, Schreiber \& Schreiber 1984, Robinson 1985, Arntz 1986, Glynn 1988). Biological effects of the 1982-1983 ENSO are also well documented for California waters. Offshore, these effects included decreased standing stocks of phytoplankton, zooplankton and fish (e.g. Fiedler 1984, McGowan 1984, 1985, Smith 1985, Fiedler et al. 1986), high mortality and low reproductive success in seabirds (Glynn 1988), and changes in microplankton species assemblages (Reid et al. 1985). In nearshore waters, there were dramatic reductions in the canopy area (Dayton \& Tegner 1984, Gerard 1984, Gaines \& Roughgarden 1987, Tegner \& Dayton 1987) and growth (Zimmerman \& Robertson 1985, Dean \& Jacobsen 1986) of the giant kelp Macrocystis pyrifera (L.) C. Ag.

We are aware, however, of only 2 published studies (Gunnill 1985, Paine 1986) that describe the effects of the 1982-1983 ENSO on rocky intertidal populations in temperate waters of the eastern North Pacific. Neither of these studies, performed at La Jolla in southern California (Gunnill 1985) and Tatoosh Island, Washington (Paine 1986), revealed dramatic changes in rocky intertidal populations during the 1982-1983 ENSO in contrast to the strong and immediate effects 
documented (see Robinson 1985, Arntz 1986, Glynn 1988) for South American intertidal systems.

The purpose of this study was to determine whether we could detect changes in the abundances and diversity of intertidal macrophytes at a central California site associated with the 1982-1983 ENSO, a potentially important, disruptive event.

\section{STUDY AREA AND ABIOTIC ENVIRONMENTAL CONDITIONS}

Study site. The study was performed ca $3 \mathrm{~km}$ southeast of Point Piedras Blancas, San Luis Obispo County, California, USA (ca $35^{\circ} 40^{\prime} \mathrm{N}$ ); detailed descriptions of the site and the abiotic environmental conditions of the region are provided elsewhere (Horn et al. 1983, Murray \& Horn 1989). The environmental conditions at the study site 3 to 5 yr before the 1982-1983 ENSO (Horn et al. 1983, Murray \& Horn 1989) were generally characteristic (see Gislén 1943, 1944, Bolin \& Abbott 1963) of non-ENSO periods for the central California coast. Seasonal variation in SSTs was minimal (List \& Koh 1976), with slightly cooler SSTs recorded during summer than during winter as a result of coastal upwelling. Daytime aerial tidal emersion was greatest in winter and spring and least in summer and autumn as was precipitation (Horn et al. 1983, Murray \& Horn 1989). Storm events, although somewhat unpredictable, occurred more frequently during non-summer months.

Onset of the 1982-1983 ENSO. Anomalously high increases in sea level began to appear along the southern California coast during the late spring of 1982 (Tegner \& Dayton 1987). From October to December 1982, unusually high SSTs were evident in satellite images for the Southern California Bight (Fiedler 1984, McGowan 1984), and positive coastal sea level and SST anomalies were apparent off the Oregon coast (Huyer \& Smith 1985a, b). Similar warm SST and sea level anomalies occurred ca $65 \mathrm{~km}$ north of our study site at Granite Canyon during November and December 1982 (Breaker \& Mooers 1986, Cannon et al. 1985). Along the central California coast, these conditions appear to have been followed (Fiedler 1984, Breaker \& Mooers 1986) by cooler SSTs and renewed coastal upwelling during the late spring and early summer months of 1983, and then by unusually high SSTs and weakened upwelling from July through December.

ENSO episodes also appear to be associated with extreme winter wave events (Seymour et al. 1984). Between December and March 1982 and during December 1983, wave heights exceeding $6 \mathrm{~m}$ were recorded on $\bar{f}$ different days (Seymour et al. 1984). These represent nearly one half of the 18 such extreme wave episodes believed to have occurred (Seymour et al. 1984) between 1900 and 1984 along the Central California coast, underscoring the severity of 1982-1983 storm events.

\section{METHODS AND MATERIALS}

Sampling program. The methods used to determine the standing stocks (percent cover) of the Piedras Blancas macrophyte populations were identical to those reported previously (Horn etal. 1983, Murray \& Horn 1989). A total of 33 permanently marked $30 \times 50 \mathrm{~cm}$ quadrats were sampled using a photographimetric technique. Quadrats were assigned to either high $(>0.90 \mathrm{~m})$, mid- $(0.31$ to 0.90 $\mathrm{m})$, or low $(\leq 0.30 \mathrm{~m}$ ) intertidal levels based on tidal height for analysis, providing a total of 6 high, 15 mid-and 12 low-level samples. Diversity was expressed as numbers of taxa and as the $H^{\prime}$ (Shannon \& Weaver 1949) and J' (Pielou 1975) indices; the last 2 values were calculated from the cover data,

Samples were taken during August 1983, when ENSO conditions were clearly apparent, and December 1983, during the latter stages of the ENSO episode (see Breaker \& Mooers 1986, Rienecker \& Mooers 1986). The December 1983 sampling took place just before the extreme wave events of December 3 , and ca 2 wk after the November storms that struck the central California coast (see Seymour et al. 1984). Data obtained from studies (Horn et al. 1983, Murray \& Horn 1989) of the same set of quadrats were used for comparisons of macrophyte abundances with those during non-ENSO periods. Data acquired during August 1983 were compared with those from 2 previous non-ENSO summers (August 1978 and July 1982); December 1983 data were compared with those from 2 previous nonENSO winters (February 1979, January 1982) and with those of December 1982, when the ENSO signal began to appear along the central California coast. The December 1982 sampling took place during the first $3 \mathrm{~d}$ of the month, immediately following a major storm.

Statistical methods. Tests of the null hypothesis of no significant difference among the ENSO summer of 1983 and previous summers, and the late ENSO winter of 1983-1984 and previous winters were made for cover and diversity data by analysis of variance (ANOVA). Data were tested for homogeneity of variances by Bartlett's test and subjected to ANOVA if equality of variances was found (Pimentel \& Smith 1986 p. 112). Percent cover data were routinely transformed to arcsin values before testing for homgeneity of variances. A Model I (fixed), Model II (random), 2-way ANOVA without replication was used for the repeated testing of the same individual sampling units, i.e., quadrats (Sokal and Rohlf 1981). The primary factor of interest, the sampling periods was the fixed factor in all 
analyses. If the data failed to meet the criteria for equality of variances, then Friedman's nonparametric method (FMRB) for ANOVA with randomized blocks was employed. Dunnett's (1955) test was used to determine whether the ENSO periods were significantly different from all pre-1983 non-ENSO summers and pre-1983-1984 winters. A nonparametric version of Dunnett's procedure was used following significant FMRB tests (Zar 1984 p. 231).

The summer and winter pre- and ENSO-influenced data were subjected separately to multivariate analysis of variance (MANOVA) and discriminant analysis. In MANOVA, an $F$ value was calculated to test the null hypothesis that the group centroids, i.e the central tendency of each winter or summer data set, were equal. Results of the discriminant analysis included, for each group centroid, canonical variate scores, 95\% confidence interval radii (in standard deviation units of discriminant space), and chi-square tests for significant differences among groups. All multivariate analyses were done separately for the high-, mid- and lowintertidal levels, using only the most abundant macrophyte populations. Most univariate and all multivariate analyses were carried out using BIOSTAT I (Pimentel \& Smith 1986) or BIOSTAT II (Pimentel \& Smith 1985) microcomputer programs.

\section{RESULTS}

\section{August 1983}

August 1983 was the summer of the ENSO. Despite major anomalies in oceanographic conditions, total macrophyte cover, numbers of taxa and $\mathrm{H}^{\prime}$ diversity were not significantly different (2-way ANOVA) in either the high-, mid-or low-intertidal levels for the non-ENSO and ENSO summers (Fig. 1). Only J' diversity for the highintertidal level varied significantly (2-way ANOVA, p < $0.05)$, dropping to 0.55 during summer of 1983 , a value significantly lower (Dunnett's test) than those $(0.68,0.65)$ obtained for the 2 non-ENSO summers.

Analyses of individual macrophyte populations produced similar results. In the high intertidal level, cover of only crustose Corallinaceae and the erect phase of Mastocarpus papillatus varied significantly over the 3 summer periods (Table 1). However, their mean cover values for the ENSO summer could not be distinguished statistically by Dunnett's test from values for both of the non-ENSO summers. In the low intertidal, cover of crustose Corallinaceae and $M$. papillatus blades varied significantly over the 3 summers (Table 1), but cover values for the ENSO summer also could not be distinguished statistically by Dunnett's test (nonparametric application). Considerably more

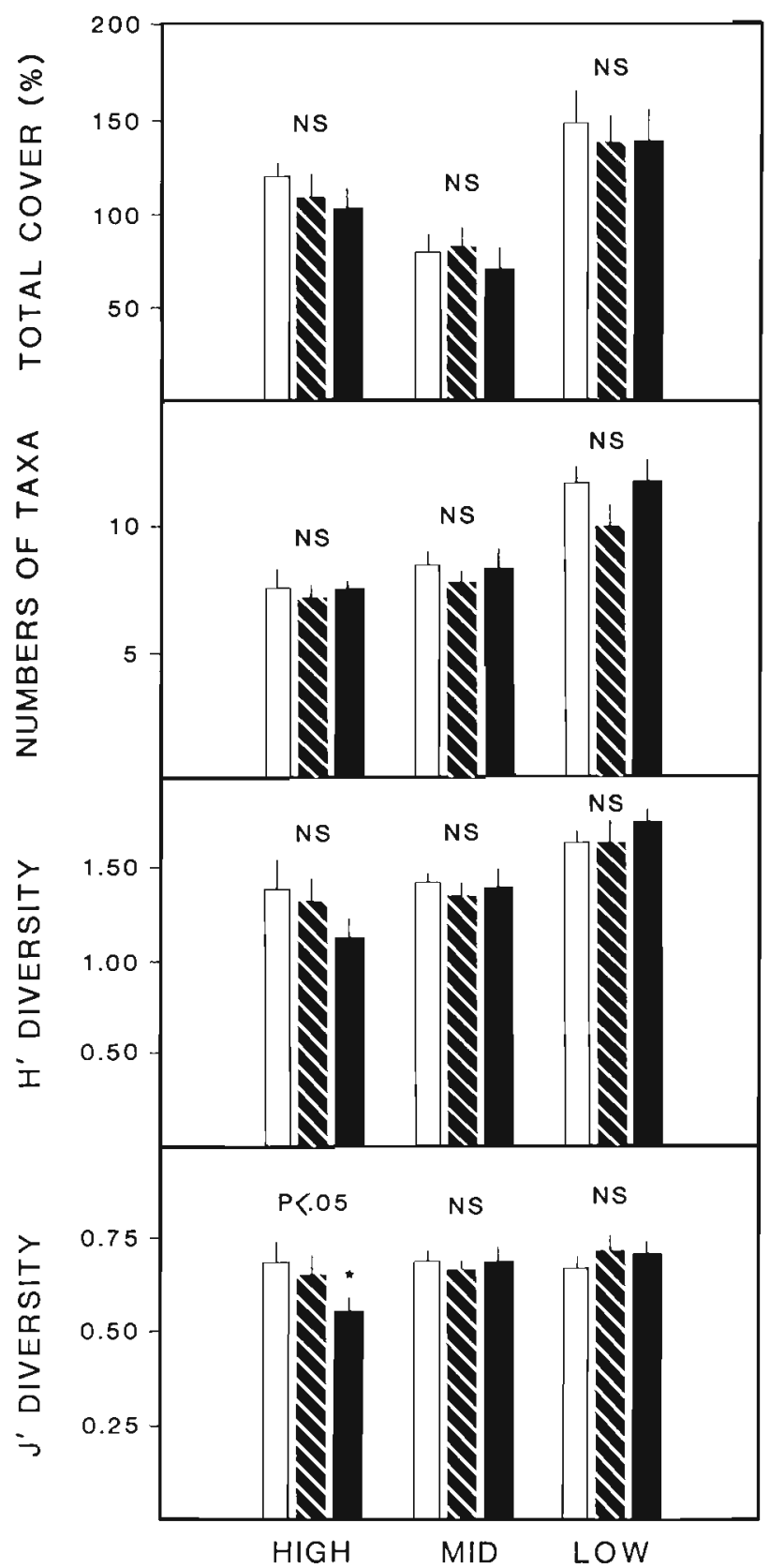

Fig. 1. Total macrophyte cover $(\%)$, numbers of taxa, $\mathrm{H}^{\prime}$ and $\mathrm{J}^{\prime}$ diversity for ENSO and pre-ENSO summer sampling periods. Pre-ENSO sampling periods are represented by open (August 1978) and cross-hatched (July 1982) vertical bars; ENSO sampling period (August 1983) is represented by the solid bars. Vertical lines depict 1 SE above the mean. Results of statistical tests (no significant difference $=n s$; significant difference and probability level $=p<0.05$ ) of the null hypothesis of no significant difference among summer sampling periods are given above the bars for each intertidal level. Analysis of nontransformed data by FMRB for numbers of taxa (high-level) and $\mathrm{H}^{\prime}$ diversity (mid-level); all other analyses by ANOVA. An asterisk above the vertical bar indicates that the August 1983 ENSO mean is significantly different from all other means based upon Dunnett's test 
year-to-year variation was apparent in the mid-intertidal level where 6 macrophytes (Corallina vancouveriensis, Gigartina canaliculata, G. leptorhynchos, Rhodoglossum affine, Ulva lobata and the erect, bladed phase of $M$. papillatus) varied significantly over the 3 summers (Table 1). However, cover for the ENSO summer was statistically distinguishable (Dunnett's test) for only U. lobata, which exhibited significantly reduced

Table 1. Comparisons of cover (\%) of abundant macrophyte populations for high-, mid- and low-intertidal levels over winter and summer periods before and during the 1982-1983 ENSO. Most statistical tests by 2-way ANOVA without replication; other analyses by Friedman's Method of Randomized Blocks (FMRB) and indicated by ${ }^{a}$. An asterisk occurs wherever cover for ENSO periods (December 1983 and August 1983) was significantly greater or less than cover for all other winter or summer periods as determined by Dunnett's test procedure

\begin{tabular}{|c|c|c|c|c|c|c|c|c|c|}
\hline \multirow[t]{2}{*}{ Taxa } & \multicolumn{4}{|c|}{ Winter } & \multicolumn{5}{|c|}{ Summer } \\
\hline & $\begin{array}{l}\text { Feb } \\
1979\end{array}$ & $\begin{array}{c}\operatorname{Jan} \\
1982\end{array}$ & $\begin{array}{c}\text { Dec } \\
1982\end{array}$ & $\begin{array}{l}\text { Dec } \\
1983\end{array}$ & $\mathrm{p}$ & $\begin{array}{l}\text { Aug } \\
1978\end{array}$ & $\begin{array}{c}\text { Jul } \\
1982\end{array}$ & $\begin{array}{l}\text { Aug } \\
1983\end{array}$ & $\mathrm{p}$ \\
\hline \multicolumn{10}{|l|}{ High-intertidal level } \\
\hline Crustose Corallinaceae & 9.8 & 16.5 & 16.3 & 20.0 & $<0.05$ & 5.6 & 11.8 & 14.6 & $<0.05$ \\
\hline Endocladia muricata (Post. \& Rupr.) J. Ag. & 26.5 & 15.0 & 24.2 & 7.9 & $<0.01$ & 14.5 & 17.6 & 29.5 & ns \\
\hline Fucus gardneri Silv. & 4.9 & 5.8 & 17.5 & 8.7 & ns & 9.4 & 16.2 & 7.7 & ns \\
\hline Hesperophycus harveyanus (Decne.) S. \& G. & 2.7 & 4.9 & 0.3 & 0.9 & $n s^{\AA}$ & 5.2 & 3.3 & 0.7 & ns \\
\hline Mastocarpus papillatus (C. Ag.) Kütz. & 7.4 & 2.9 & 4.2 & 0.4 & $<0.05$ & 26.4 & 9.8 & 5.5 & $<0.01$ \\
\hline Noncalcareous crustose algae & 4.8 & 20.0 & 17.9 & 5.3 & $<0.05$ & 5.0 & 5.1 & 3.7 & $n s^{d}$ \\
\hline Pelvetia fastigiata (J. Ag.) DeToni & 35.1 & 43.1 & 41.4 & 33.9 & ns & 41.0 & 39.9 & 37.4 & ns \\
\hline Other macrophytes & 8.9 & 1.7 & 1.4 & 0.6 & & 10.8 & 4.2 & 3.2 & \\
\hline Total high-level cover & 100.1 & 109.9 & 123.2 & 77.7 & $<0.01^{\circ}$ & 117.9 & 107.9 & 102.3 & ns \\
\hline \multicolumn{10}{|l|}{ Mid-intertidal level } \\
\hline Crustose Corallinaceae & 1.2 & 2.2 & 2.1 & 5.0 & $<0.01^{\circ}$ & 0.7 & 0.6 & 1.1 & ns \\
\hline Corallina vancouveriensis Yendo & 3.0 & 3.3 & 2.5 & 4.0 & ns & 0.9 & 1.9 & 2.3 & $<0.05$ \\
\hline Endocladia muricata (Post. \& Rupr.) J. Ag. & 5.0 & 2.4 & 2.0 & 2.6 & ns & 2.3 & 3.4 & 3.6 & ns \\
\hline $\begin{array}{l}\text { Gastroclonium subarticulatum (Turn.) Kütz. } \\
\text { Gelidium coulteri Harv. \& }\end{array}$ & 0.1 & 1.9 & 3.1 & 3.7 & $\mathrm{~ns}^{\mathrm{a}}$ & 1.0 & 1.3 & 3.3 & $n s^{d}$ \\
\hline G. pusillum (Stackh.) LeJolis & 3.9 & 5.1 & 3.4 & 9.8 & $n s^{a}$ & 4.9 & 4.4 & 5.9 & ns \\
\hline Gigartina canaliculata Harv. & 17.4 & 15.4 & 16.0 & 9.7 & ns & 14.7 & 10.2 & 8.7 & $=0.05$ \\
\hline Gigartina leptorhynchos J. Ag. & 0.1 & 0.1 & 2.6 & 0.7 & $n s^{a}$ & $<0.1$ & 0.8 & 1.5 & $<0.05^{\circ}$ \\
\hline Iridaea cordata var. cordata (Turn.) Bory & 0.6 & 2.0 & 2.4 & 0.0 & $n s^{\alpha}$ & 2.5 & 6.9 & 3.0 & ns \\
\hline Mastocarpus papillatus (C. Ag.) Kütz. & 7.6 & 13.9 & 13.5 & 1.6 & $<0.001^{\circ}$ & 16.0 & 28.7 & 16.4 & $<0.01$ \\
\hline Noncalcareous crustose algae & 13.9 & 15.4 & 7.8 & 18.9 & $<0.001$ & 2.8 & 5.2 & 4.7 & ns \\
\hline Pelvetia fastigiata (J. Ag.) DeToni & 1.1 & 3.3 & 0.7 & $<0.1$ & $\mathrm{~ns}^{\mathrm{a}}$ & 0.2 & 1.6 & 0.3 & $n s^{a}$ \\
\hline Rhodoglossum affine (Harv.) Kyl. & 12.9 & 5.2 & 12.2 & 11.0 & $=0.01$ & 7.3 & 14.0 & 16.6 & $<0.01$ \\
\hline Ulva lobata (Kütz.) S. \& G. & 0.5 & $<0.1$ & 2.4 & $<0.1$ & $n s^{2}$ & 17.2 & 1.4 & 0.3 & $<0.01^{\circ} \cdot a$ \\
\hline Other macrophytes & 0.5 & 1.0 & 1.9 & 0.7 & & 7.6 & 0.7 & 2.2 & \\
\hline Total mid-level cover & 67.8 & 71.3 & 72.6 & 67.9 & ns & 78.2 & 81.1 & 69.9 & ns \\
\hline \multicolumn{10}{|l|}{ Low-intertidal level } \\
\hline Crustose Corallinaceae & 6.6 & 10.4 & 5.5 & 27.2 & $<0.001^{\circ} \cdot 8$ & 7.3 & 2.0 & 5.0 & $<0.05^{\mathrm{a}}$ \\
\hline Corallina vancouveriensis Yendo & 1.3 & 2.4 & 0.8 & 2.6 & ns & 0.5 & 0.6 & 1.9 & $n s^{a}$ \\
\hline Egregia menziesii (Turn.) Aresch. & 0.0 & 0.0 & 4.3 & 12.4 & $n s^{a}$ & 3.0 & $<0.1$ & 8.5 & $\mathrm{~ns}^{\mathrm{d}}$ \\
\hline \multicolumn{9}{|l|}{ Gelidium coulteri Harv. \& } & ns \\
\hline G. pusillum (Stackh.) LeJolis & 2.3 & 3.7 & 1.5 & 3.0 & ns & 1.0 & 1.9 & 2.2 & ns \\
\hline Gigartina canaliculata Harv. & 12.8 & 7.0 & 11.7 & 4.8 & ns & 20.5 & 18.4 & 11.1 & ns \\
\hline Gigartina leptorhynchos J. Ag. & 1.1 & 0.2 & 1.1 & 2.3 & $n s^{\hat{a}}$ & 1.0 & 1.5 & 3.0 & ns \\
\hline Gigartina spinosa (Kütz.) Harv. & 0.5 & 0.2 & 0.8 & 0.5 & ns & 1.5 & 0.5 & 1.4 & ns \\
\hline Inidaea cordata var. cordata (Turn.) Bory & 1.7 & 2.1 & 3.3 & 0.5 & ns & 11.2 & 21.1 & 9.0 & ns \\
\hline Macrocystis integrifolia Bory & 13.1 & 16.3 & 24.2 & 16.3 & ns & 16.8 & 18.7 & 14.9 & ns \\
\hline Mastocarpus papillatus (C. Ag.) Kütz. & 7.3 & 9.1 & 10.8 & 2.0 & ns & 3.4 & 16.9 & 6.4 & $<0.05^{\mathrm{a}}$ \\
\hline Noncalcareous crustose algae & 8.2 & 9.4 & 6.5 & 7.8 & ns & 1.4 & 6.3 & 6.5 & $n s^{\alpha}$ \\
\hline Phyllospadix scouleri Hook. & 42.2 & 38.0 & 29.6 & 18.3 & ns & 37.0 & 17.1 & 34.6 & ns \\
\hline Prionitis lanceolata (Harv.) Harv. & 0.3 & 1.6 & 1.0 & 2.5 & ns & 0.2 & 0.5 & 4.0 & $\mathrm{~ns}^{\mathrm{c}}$ \\
\hline Rhodoglossum affine (Harv.) Kyl. & 5.5 & 3.1 & 4.6 & 4.1 & ns & 6.6 & 7.9 & 3.2 & ns \\
\hline Smithora naiadum (Anders.) Hollenb. & $<0.1$ & 0.0 & $<0.1$ & 0.0 & $n s^{\hat{a}}$ & 4.1 & 1.1 & 1.3 & ns \\
\hline Ulva lobata (Kütz.) S. \& G. & 1.8 & 0.5 & 3.2 & 0.3 & $<0.05^{3}$ & 15.8 & 8.1 & 4.8 & ns \\
\hline Other macrophytes & 5.1 & 1.2 & 17.7 & 15.5 & & 14.1 & 6.0 & 16.4 & \\
\hline Total low-level cover & 112.2 & 109.2 & 128.2 & 123.1 & ns & 146.4 & 136.1 & 136.4 & ns \\
\hline
\end{tabular}


Cover during the ENSO summer of 1983. Neither MANOVA nor discriminant analysis distinguished the ENSO summer from non-ENSO summer periods at any of the 3 intertidal levels (Table 2).

\section{December 1983}

December 1983 was the winter during the latter stages of the 1982-1983 ENSO. Total macrophyte cover was significantly less (2-way ANOVA, Dunnett's test) in the high intertidal during December 1983 but did not vary significantly in the mid-and low-levels over the 4 winter periods (Fig. 2). No significant differences were obtained for $\mathrm{H}^{\prime}$ or $\mathrm{J}^{\prime}$ diversity for any of the 3 intertidal levels over the 4 winter periods (Fig. 2). However, numbers of taxa varied significantly among winters (Fig. 2), and these differences occurred in both the high- and low-intertidal levels; Dunnett's test, however, failed to distinguish the late-ENSO winter of December 1983 from the other 3 winter periods.

Only 3 mid-and low-, and none of the high-intertidal populations significantly increased or decreased in cover during the late-ENSO winter of 1983-1984 (Table 1). In the mid-intertidal, significantly greater cover of crustose Corallinaceae and a significant reduction in cover of the erect, bladed phase of Mastocarpus papillatus occurred during December 1983 (Table 1). In the low-intertidal, cover of crustose Corallinaceae was significantly greater during the late-ENSO winter of 1983-1984 (Table 1). Statistically significant variations in cover were obtained among the 4 winter periods for Gastroclonium subarticulatum and Ulva lobata in the low-level, Rhodoglossum affine and noncalcareous crustose algae (a taxon including the crustose phase of M. papillatus) in the mid-level, and crustose Corallinaceae, noncalcareous crustose algae, Endocladia muricata and the erect phase of $M$. papillatus in the high-level; however, cover of none of these taxa during December 1983 was statistically distinguishable from values recorded for each of the other 3 winter periods.

Unlike the case for intersummer comparisons, our multivariate analyses showed that the late-ENSO winter samples were significantly different from those of the other 3 winters at all 3 intertidal levels (Table 3; Fig. 3). The centroid for December 1982, when ENSO conditions had just begun to develop along the central California coast, formed a single group with 2 nonENSO winters (February 1979 and January 1982).

\section{DISCUSSION}

Our results show that the major anomalies in eastern North Pacific oceanographic conditions during the 1982-1983 ENSO did not produce dramatic and immediate changes in the distributions and abundances of macrophyte populations on central California shores.

These findings are in agreement with the results of Gunnill (1985) and Paine (1986) for other eastern North Pacific intertidal populations. Paine (1986) was not able to demonstrate unambiguous ENSO effects on distributional limits, recruitment or algal growth and mortality at an exposed site on the northwestern Washington coast. He emphasized that the effects of even a potentially strong disturbance such as an ENSO can be difficult to detect or interpret owing to the high level of

Table 2. Results of MANOVA tests of equality of group centroids, chi-square tests of significance of eigenvalues, and amount of among group differences extracted by the first 2 canonical axes (\% trace) for ENSO and non-ENSO summer data collections. Values shown separately for high-, mid-and low-intertidal samples based on percent cover data for abundant macrophytes

\begin{tabular}{|c|c|c|c|c|c|}
\hline $\begin{array}{l}\text { Statistical } \\
\text { procedure }\end{array}$ & F & $x^{2}$ & DF & $\mathrm{p}$ & $\begin{array}{c}\text { Cumulative } \\
\% \text { trace }\end{array}$ \\
\hline \multicolumn{6}{|c|}{ High-intertidal level ( 6 populations) } \\
\hline MANOVA & 1.41 & & 12,20 & 0.240 & \\
\hline \multicolumn{6}{|l|}{ Chi-square } \\
\hline Axis 1 & & 15.33 & 12 & 0.225 & 96.4 \\
\hline Axis 2 & & 0.97 & 5 & 0.963 & 100.0 \\
\hline \multicolumn{6}{|c|}{ Mid-intertidal level (12 populations) } \\
\hline MANOVA & 1.33 & & 24,62 & 0.183 & \\
\hline \multicolumn{6}{|l|}{ Chi-square } \\
\hline Axis 1 & & 30.33 & 24 & 0.178 & 75.5 \\
\hline Axis 2 & & 8.58 & 11 & 0.662 & 100.0 \\
\hline \multicolumn{6}{|c|}{ Low-intertidal level (12 populations) } \\
\hline MANOVA & 1.70 & & 24,44 & 0.063 & \\
\hline \multicolumn{6}{|l|}{ Chi-square } \\
\hline Axis 1 & & 36.05 & 24 & 0.057 & 55.1 \\
\hline Axis 2 & & 16.67 & 11 & 0.120 & 100.0 \\
\hline
\end{tabular}




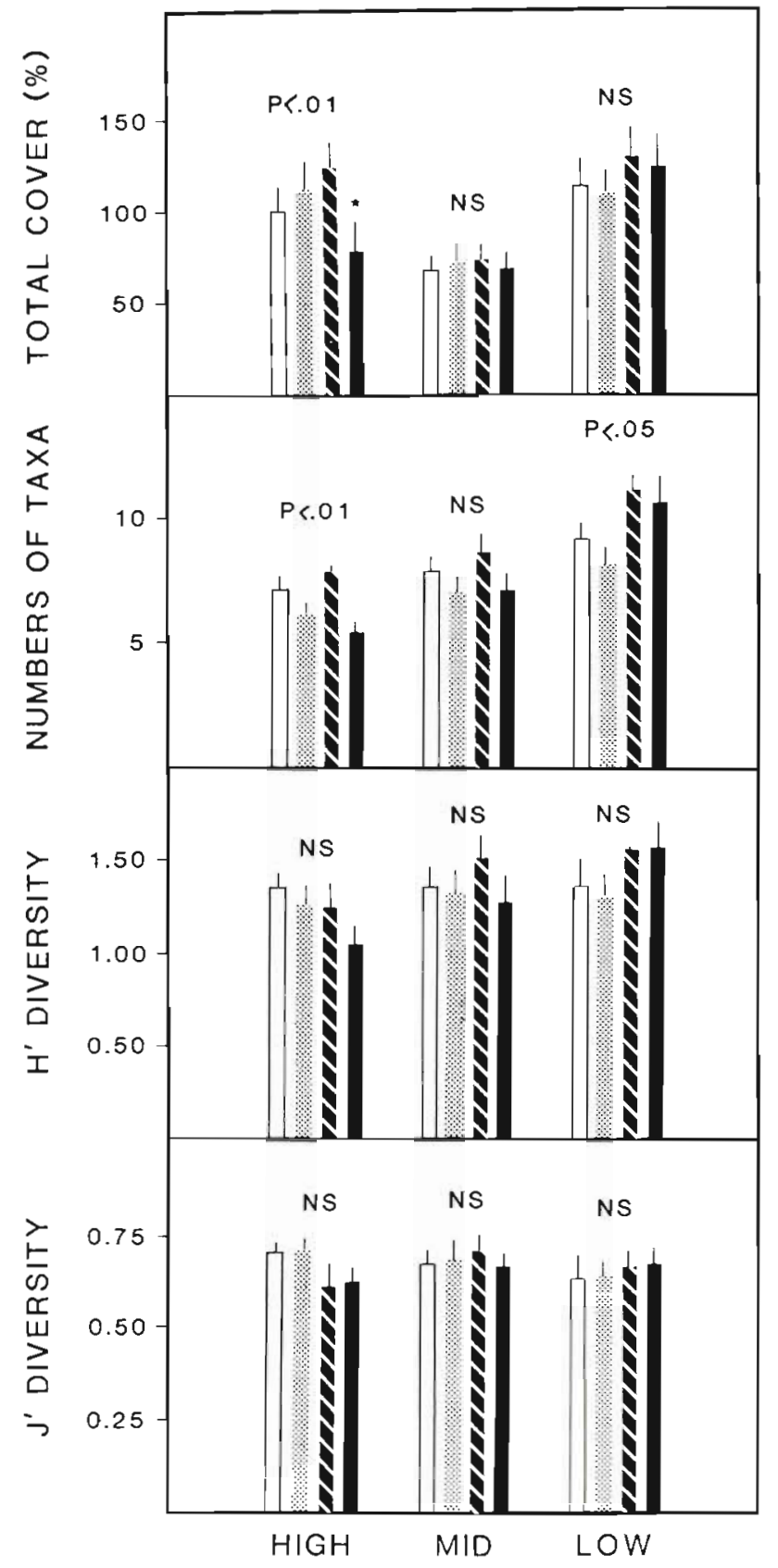

Fig. 2. Total macrophyte cover (\%), numbers of taxa, $\mathrm{H}^{\prime}$ and $\mathrm{J}^{\circ}$ diversity for ENSO and pre-ENSO winter sampling periods. Pre-ENSO sampling periods are represented by open (February 1979), and stippled (January 1982) vertical bars. The winter sampling period at the outset of the 1982-1983 ENSO (December 1982) is represented by cross-hatched vertical bars, whereas the late ENSO sampling period (December 1983 ) is represented by the solid bars. Vertical lines depict $1 \mathrm{SE}$ above the mear1. Results of statistical tests (no significant difference $=n$ s; significant difference and probabijity level $=$ $p<0.05, p<0.01$ ) of the null hypothesis of no significant difference among summer sampling periods are given above the vertical bars for each intertidal level. All analyses by ANOVA. An asterisk above the vertical bar indicates that the December 1983 ENSO mean is significantly different from all other means based upon Dunnett's test

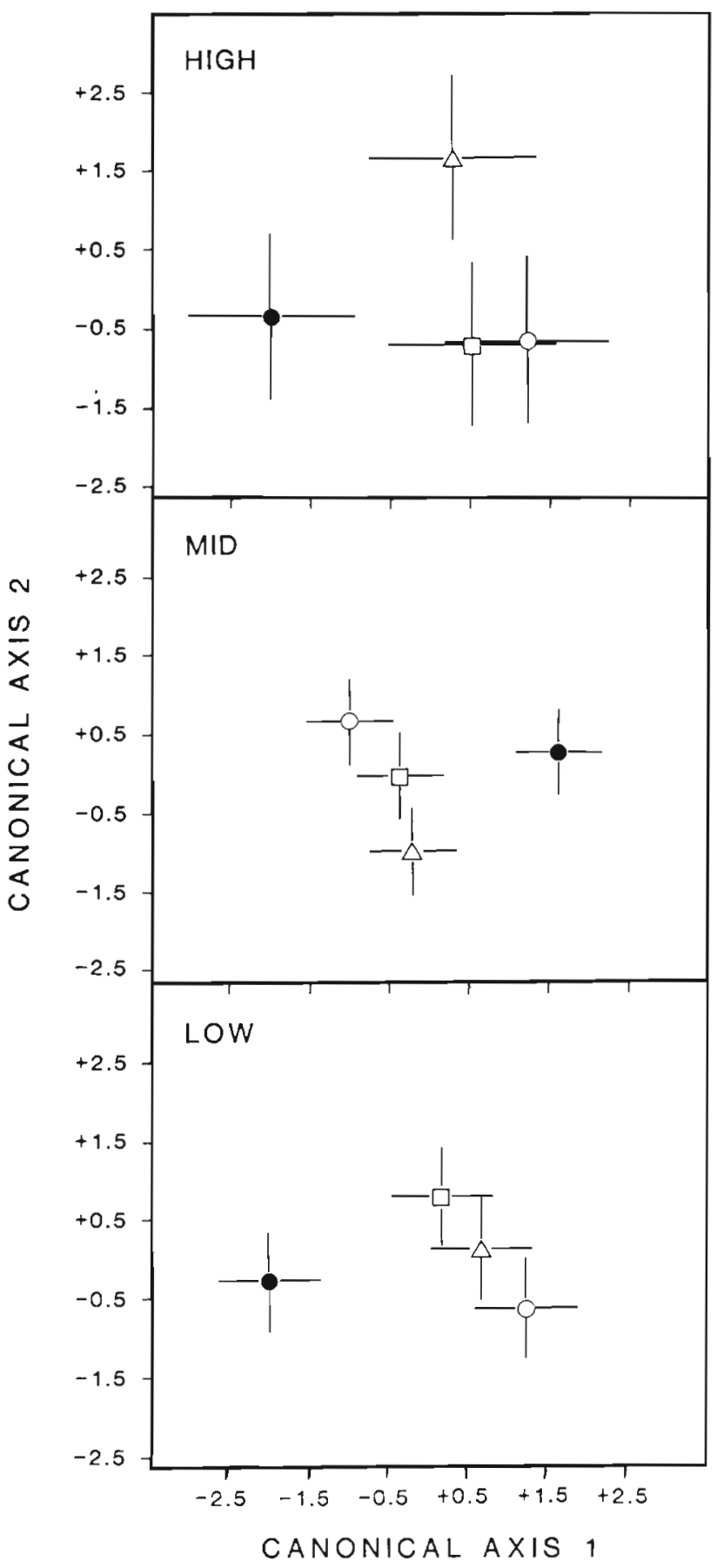

Fig. 3. Plots of group centroids $\pm 95 \%$ confidence intervals as radii for winter sampling periods in discriminant 2-space for high-, mid-and low-intertidal levels. Depicted are the first 2 canonical axes. Significant discrimination of group centroids is apparent for the first canonical axis in all plots. Pre-ENSO February 1979 ( ) and January 1982 ( ) ), and the early ENSO December 1982 centroids are represented by the symbols inclicated, whereas the late ENSO centroid (December 1983) is represented by $(\bullet)$ 
Table 3. Results of MANOVA tests of equality of group centroids, chi-square tests of significance of eigenvalues, and amount of among group differences extracted by the first 2 canonical axes (\% trace) for ENSO and non-ENSO winter data collections. Values shown separately for high-, mid- and low-intertidal samples based on percent cover data for abundant macrophytes

\begin{tabular}{|c|c|c|c|c|c|}
\hline $\begin{array}{l}\text { Statistical } \\
\text { procedure }\end{array}$ & F & $x^{2}$ & DF & $\mathrm{p}$ & $\begin{array}{c}\text { Cumulative } \\
\% \text { trace }\end{array}$ \\
\hline \multicolumn{6}{|c|}{ High-intertidal level (6 populations) } \\
\hline MANOVA & 2.40 & & 18,42 & 0.010 & \\
\hline \multicolumn{6}{|l|}{ Chi-square } \\
\hline Axis 1 & & 35.51 & 18 & 0.009 & 56.2 \\
\hline Axis 2 & & 17.31 & 10 & 0.069 & 92.9 \\
\hline \multicolumn{6}{|c|}{ Mid-intertidal level (11 populations) } \\
\hline MANOVA & 2.20 & & 33,136 & 0.001 & \\
\hline \multicolumn{6}{|l|}{ Chi-square } \\
\hline Axis 1 & & 64.74 & 33 & 0.001 & 61.5 \\
\hline Axis 2 & & 28.46 & 20 & 0.102 & 85.4 \\
\hline \multicolumn{6}{|c|}{ Low-intertidal level (12 populations) } \\
\hline MANOVA & 1.61 & & 36,98 & 0.033 & \\
\hline \multicolumn{6}{|l|}{ Chi-square } \\
\hline Axis 1 & & 53.56 & 36 & 0.033 & 78.1 \\
\hline Axis 2 & & 15.88 & 22 & 0.821 & 92.5 \\
\hline
\end{tabular}

temporal variation exhibited by benthic systems. Similarly, Gunnill (1985), working on southern California shores, did not find a uniform pattern in the growth, mortality or recruitment responses of seven intertidal macroalgae during the 1982-1983 ENSO period probably because of the high degree of natural interannual variability known (Gunnill 1980, 1985) to occur in these populations.

Our data contrast markedly with reports (Laurie 1983, 1984, 1985, 1987, Robinson 1985, Soto 1985, Tomicic 1985, Arntz 1986, Glynn 1988) of ENSO-influenced changes in South American rocky intertidal systems. In South America, declines occurred in the abundances of the brown algae Sargassum sp. and Blossevillea galapagensis (Picc. \& Grun.) Tayl. in the Galápagos archipelago (Robinson 1985) and in Chilean populations of the large, lower shore kelps Lessonia nigrescens Bory and Macrocystis integrifolia (Soto 1985, Tomicic 1985). Increases in the abundances of several algae including Ulva, Enteromorpha and Iridaea spp. also were reported for Chilean shores (Soto 1985), whereas decreases in the abundances of Ulva, Spermothamnion and Centroceras spp., the principal algal food resources for marine iguanas, were observed in the Galápagos Islands (Laurie 1983, 1984, 1985. 1987). Additionally, the mass mortality of barnacles and small mytilid bivalves accompanied by reductions in grazing invertebrates resulted (Arntz 1986) in extremely large increases in algal cover on certain South American shores.

Our data indicate that significant differences in macrophyte abundances and diversity were evident only during the winter of 1983-1984. Quantitative differences in macrophyte abundances and diversity from
non-ENSO summers could not be demonstrated for August 1983 when ENSO conditions were strongly evident along the central California coast. Qualitatively, we noticed that several species of red algae such as Porphyra perforata J. Ag., Iridaea cordata var. cordata, Laurencia spectabilis var. spectabilis Post. \& Rupr., Prionitis lanceolata, Gastroclonium subarticulatum, and Gigartina canaliculata were unusually green in color during September 1983, a finding similar to observations made at nearby Diablo Cove by Wheeler North (pers. comm.) during the same month.

For December 1983, the most outstanding difference from non-ENSO winters was that the expected increases (Horn et al. 1983, Murray \& Horn 1989) in the cover of crustose Corallinaceae were much greater than 'normal', particularly in the mid- and low-intertidal. These algae are known to have low primary productivities (Littler \& Littler 1980, Littler \& Arnold 1982), to have tough thalli that are resistant to physical stress (Littler \& Littler 1980, Lubchenco \& Gaines 1981 , Sousa et al. 1981), and to become increasingly abundant in disturbed habitats (Murray \& Littler 1984). The December 1983 increase in primary cover of crustose algae was probably associated with the observed decreases in the abundances of erect, fleshy seaweeds such as the bladed phase of Mastocarpus papillatus that grow over crust-inhabiting substratum, rather than with the actual recruitment of new individuals.

In California, the unusual mass mortalities of kelpforest fishes (Bodkin et al. 1987) and destruction of Macrocystis pyrifera canopies and resultant modification of kelp bed communities (Dayton \& Tegner 1984, Harris et al. 1984, Ebeling et al. 1985) were among the documented effects of the unusually severe (Seymour 
et al. 1984) winter storms of 1982-1983 and 1983-1984. Dayton and Tegner (1984) stressed the difficulties in separating ENSO effects correlated with high SSTs (and nutrient-poor water) or elevated sea level from those associated with storm disturbances. Seymour et al. (1984), however, established a significant correlation between large wave events and northern hemisphere winters during ENSO years, suggesting that increased winter storm activity is part of the suite of anomalies resultant from ENSO modifications of coastal oceanographic conditions. Despite the magnitude of these ENSO-associated storms, our data suggest that these events had little short-term effect on abundances and diversity of central California intertidal macrophytes, and that their impact could be measured perhaps only during December 1983 following the ENSO summer. The December 1982 sampling was done immediately following the extreme wave episodes recorded by Seymour et al. (1984) for mid-November and early-December, and the August 1983 assessments occurred 5 to 7 mo after the 5 large storms that took place between January and March 1983. However, our multivariate analyses failed to discriminate August 1983 and December 1982 from previous summers and winters when storm-associated wave action was less intense. Also, any unusual deviations from the established patterns (Horn et al. 1983, Murray \& Horn 1989) of moderate winter increases in cover of crustose algae and decreases in fleshy red algae could not be detected.

The absence of quantifiable short-term changes in the distributions and abundances of central California intertidal macrophytes perhaps is to be expected because ENSO oceanographic and atmospheric anomalies diminished in intensity from south to north along the North American coast. Nevertheless, the 1982-1983 ENSO signal was clearly strong in California waters and, as occurred in South America, dramatic changes in pelagic coastal populations were readily recognized and documented (e.g. Fiedler 1984, McGowan 1984, 1985, Smith 1985, Fiedler et al 1986) during the 1982-1983 ENSO. Our sampling efforts may have failed to provide adequate time-series data to demonstrate ENSO-associated changes in rocky intertidal habitats as these systems are known for their high degree of temporal variability (e.g. Lewis 1976, 1977, Hartnoll \& Hawkins 1980, Hawkins \& Hartnoll 1983, Baxter et al. 1985, Paine 1986). Unfortunately, longterm records of the variation and persistence of benthic populations are extremely rare for intertidal communities (e.g. Lewis 1976, Jones et al. 1979, Connell 1986, Wolfe et al. 1987), including those occurring in California. Thus, only the most obvious and major short-term impacts of events such as the 1982-1983 ENSO are likely to be resolved.
Acknowledgements. Margaret Neighbors, Dennis Hagner Kevan Urquhart, Cheryl Scannell, Kirk Stoddard, and Candace Irelan provided able assistance in assessing macrophyte abundances Wheeler North kindly made available data from his research at Diablo Cove. Dennis Hagner and Gayle Gutierrez assisted in various aspects of the data analyses, as did Candace Irelan who also prepared the illustrations. We appreciate the assistance of Mia Tegner who directed us towards important ENSO literature. James D. Smith, Richard A. Pimentel and Paul N. DeLand provided useful suggestions on statistical procedures. This study was supported in part by National Science Foundation grants OCE-8109599, OCE8218797 and OCE 87-16368. This paper is Ocean Studies Institute contribution no. 61 .

\section{LITERATURE CITED}

Arntz, W. E. (1986). The two faces of El Niño 1982-83. Meeresforsch. 31: $1-46$

Barber, R. T., Chávez, F. P. (1983). Biological consequences of El Niño. Science 222: 1203-1210

Barber, R. T., Chávez, F. P. (1986). Ocean variability in relation to living resources during the 1982-83 El Niño. Nature, Lond 319: 279-285

Baxter, J. M., Jones, A. M., Simpson, J. A. (1985). A study of long-term changes in some rocky shore communities in Orkney. Proc. R. Soc. Edinb. 87 (Sect. B): 47-63

Bodkin, J. L., Van Blaricom, G. R., Jameson, R. J. (1987). Mortalities of kelp-forest fishes associated with large oceanic waves off central California, 1982-1983. Envir. Biol. Fish. 18: 73-76

Bolin, R. L., Abbott, D. P. (1963). Studies on the climate and phytoplankton of the central coastal area of California, 1954-1960. Rep. Calif. coop. oceanic. Fish. Invest. 9: 23-45

Breaker, L. C., Mooers, C. N. K. (1986). Oceanic variability off the central California coast. Prog. Oceanogr. 17:61-135

Cane, M. A. (1983). Oceanographic events during El Nin̄o. Science 222: 1189-1195

Cannon, G. A., Reed, R. K., Pullen, P. E. (1985). Comparison of El Niño events off the Pacific northwest. In: Wooster, W. S., Fluharty, D. L. (eds.) El Niño north. Niño effects in the eastern Subarctic Pacific Ocean. Washington Sea Grant Program, Univ. Washington, Seattle, p. 75-84

Connell, J. H. (1986). Variation and persistence of rocky shore populations. In: Moore, P. G., Seed, R. (eds.) The ecology of rocky coasts. Columbia University Press, New York, p. $57-69$

Dayton, P. K., Tegner, M. J. (1984). Catastrophic storms, El Niño, and patch stability in a southern California kelp community. Science 224: 283-285

Dean, I A., Jacobsen, F. R. (1986). Nutrient-limited growth of juvenile kelp, Macrocystis pyrifera, during the 1982-1984 'El Niño' in southern California. Mar. Biol. 90: 597-601

Dunnett, C W. (1955). A multiple comparison procedure for companng several treatments with a control. J. Am. statist. Ass. 75: 789-795

Ebeling, A. W., Laur, D. R., Rowley, R. J. (1985). Severe storm disturbances and reversal of community structure in a southern California kelp forest. Mar. Biol. 84: 287-294

Feldman, G., Clark, D., Halpem, D. (1984). Satellite color observations of the phytoplankton distribution in the eastern equatorial Pacific during the 1982-1983 El Nino. Sc1ence 226: 1069-1071

Fiedler, P. C. (1984). Satellite observations of the 1982-1983 El Nino along the U.S. Pacific coast. Science 224: 1251-1254

Fiedler, P. C, Methot, R. D., Hewitt, R. P. (1986). Effects of 
California El Niño 1982-1984 on the northern anchovy. J. mar. Res. 44: 317-338

Gaines, S. D., Roughgarden, J. (1987). Fish in offshore kelp forests affect recruitment to intertidal barnacle populations. Science 235: 479-481

Gerard, V (1984). Physiological effects of El Niño on giant kelp in southern California. Mar Biol. Lett. 5: 317-322

Gislén, $\Upsilon$ (1943). Physiographical and ecological investigations concerning the littoral of the northern Pacific. Sections I. Lunds Univ. Åsskrift. N. F. Avd. 2. 39: 1-63

Gislén, T (1944). Physiographical and ecological investigations concerning the littoral of the northern Pacific. Sections II-IV Lunds Univ. Arsskrift. N. F. Avd. 2. 40: 1-91

Glynn, P. W (1988). El Nino-Southern Oscillation 1982-1983: nearshore population, community, and ecosystem responses. A. Rev. Ecol Syst. 19: 309-345

Gunnill, F. C. (1980). Recruitment and standing stocks in populations of one green alga and five brown algae in the intertidal zone near La Jolla, California during 1973-1977 Mar. Ecol. Prog. Ser. 3: 231-243

Gunnill, F. C. (1985). Population fluctuations of seven macroalgae in southern California during 1981-1983 including effects of severe storms and an El Niño. J. exp. mar. Biol. Ecol. 85: 149-164

Halpern, D., Hayes, S. P., Leetmaa, A., Hansen, D. V., Philander, S. G. H. (1983). Oceanographic observations of the 1982 warming of the tropical eastern Pacific. Science 221: $1173-1175$

Harris, L. G., Ebeling, A. W., Laur, D. R., Rowley, R. J. (1984). Community recovery after storm damage: a case of facilitation in primary succession. Science 224: 1336-1338

Hartnoll, R. G., Hawkins, S. J. (1980). Monitoring rocky-shore communities: a critical look at spatial and temporal variation. Helgoländer Meeresunters. 33: 484-494

Hawkins, S. J. Hartnoll, R. G. (1983). Changes in a rocky shore community: an evaluation of monitoring. Mar. envirl Res. 9. $131-181$

Horn, M. H., Murray, S. N., Seapy, R. R. (1983). Seasonal structure of a central California rocky intertidal community in relation to environmental variations. Bull. Sth. Calif. Acad. Sci. 82: 79-94

Huyer, A., Smith, R. L. (1985a). The signature of El Niño off Oregon, 1982-1983. J. geophys. Res. 90: 7133-7142

Huyer, A., Smith, R. L. (1985b). The apparition of El Niño off Oregon in 1982-83. In: Wooster, W S., Fluharty, D. L. (eds.) El Niño north. Niño effects in the eastern Subarctic Pacific Ocean. Washington Sea Grant Program, Univ. Washington, Seattle, p. 73-74

Jones, W. E., Fletcher, A., Bennell, S., McConnell, B. Smith, S. M. (1979). Changes in littoral populations as recorded by long term shore surveillance. 1. Selected examples of cyclic changes. In: Naylor, E., Hartnoll, R. G. (eds.) Cyclic phenomena in marine plants and animals. Proc. 13th Eur. mar. Biol. Symp. Pergamon Press, Oxford, p. 93-100

Laurie, A. (1983). An ill wind for iguanas. New Scient. 100: 108

Laurie, A. (1984). El Niño causa estragos nunca vistos en la población de iguanas marinas. Boln Estud. Reg. Fenó. El Niño (Quito) 11: 15-18

Laurie, A. (1985). The effects of the 1982-83 El Niño on marine iguanas. In: Robinson, G., del Pino, E. M. (eds.) El Niño en las Galápagos: el evento de 1982-1983. Fundacíon Charles Darwin para las Islas Galápagos, Quito, Ecuador, p. 199-209

Laurie, A. (1987). Marine iguanas: living on the ocean margin. Oceanus 30: 54-60
Lewis, J. R. (1976). Long-term ecological surveillance: practical realities in the rocky littoral. Oceanogr mar Biol. A. Rev, 14: 371-390

Lewis, J. R. (1977). The role of physical and biological factors in the distribution and stability of rocky shore communities. In: Keegan, B. F., O Céidigh, P., Boaden, P. J. S. (eds.) Biology of benthic organisms. Proc. 11th Eur. mar Biol. Symp. Pergamon Press, Oxford, p. 417-424

List, E. J., Koh, R. C. Y (1976). Variations in coastal temperatures on the southern central California coast. J. geophys. Res. 81: 1971-1979

Littler, M. M., Arnold, K. E. (1982). Primary productivity of marine macroalgal functional-form groups from southwestern North America. J. Phycol. 18: 307-311

Littler, M. M., Littler, D. S. (1980). The evolution of thallus form and survival strategies in benthic marine macroalgae: field and laboratory tests of a functional form model. Am. Nat, 116: 25-44

Lubchenco, J., Gaines, S. D. (1981). A unified approach to marine plant-herbivore interactions. I. Populations and communities. A. Rev. Ecol. Syst. 12: 405-437

McGowan, J. A. (1984). The California El Niño, 1983. Oceanus 27: $48-51$

McGowan, J. A. (1985). El Niño 1983 in the Southern California Bight. In: Wooster, W. S., Fluharty, D. L. (eds.) El Niño north. Niño effects in the eastern Subarctic Pacific Ocean. Washington Sea Grant Program, Univ. Washington, Seattle, p. 166-184

Murray, S. N. Horn, M. H. (1989). Seasonal dynamics of macrophyte populations from an eastern North Pacific rocky intertidal habitat. Botanica Mar 32: (in press)

Murray, S. N., Littler, M. M. (1984). Analysis of seaweed communities in a disturbed rocky intertidal environment near Whites Point, Los Angeles, California, USA. Hydrobiol. 116/117: 374-382

Norton, J., McLain, D., Brainard, R., Husby, D. (1985). The 1982-83 El Niño event off Baja and Alta California and its ocean climate context. In: Wooster, W. S., Fluharty, D. L. (eds.) El Niño north. Niño effects in the eastern Subarctic Pacific Ocean. Washington Sea Grant Program, Univ. Washington, Seattle, p. 44-72

Paine, R. T (1986). Benthic community-water column coupling during the 1982-1983 El Nino. Are community changes at high latitudes attributable to cause or coincidence? Limnol. Oceanogr. 31: 351-360

Pielou, E. C. (1975). Ecological diversity. John Wiley \& Sons, New York

Pimentel, R. A., Smith, J. D. (1985). BIOSTAT II. A multivariate statistical toolbox. Sigma Soft, Placentia, California

Pimentel, R. A., Smith, J. D. (1986). BIOSTAT I. A univariate statistical toolbox. Sigma Soft, Placentia, California

Quiroz, R. S. (1983). The climate of the 'El Nino' winter of 1982-83 - a season of extraordinary climatic anomalies. Mon. Weather Rev. 111: 1685-1706

Rasmusson, E. M., Wallace, J. M. (1983). Meteorological aspects of the El Niño/Southern Oscillation. Science 222: 1195-1202

Reid, F. M. H., Lange, C. B., White, M. M. (1985). Microplankton species assemblages at the Scripps Pier from March to November 1983 during the 1982-1984 El Niño event. Botanica Mar 28: 443-452

Rienecker, M. M., Mooers, C. N. K. (1986). The 1982-1983 El Niño signal off northern California. J. geophys. Res. 91: $6597-6608$

Robinson, G. (1985). Influence of the 1982-83 El Niño on Galápagos marine life. In: Robinson, G., del Pino, E. M. (eds.) El Niño en las Galápagos: el evento de 1982-1983. 
Fundacion Charles Darwin para las Islas Galápagos, Quito, Ecuador, p. 153-190

Schreiber, R. W., Schreiber, E. A. (1984). Central Pacific seabirds and the El Nino Southern Oscillation: 1982 to 1983 perspectives. Science 225: 713-716

Seymour, R. J., Strange, R. R., III., Cayan, D. R., Nathan, R. A. (1984). Influence of El Ninos on California's wave climate. In: Edge, B. L. (ed.) Nineteenth Coastal Engineering Conference, September 3-7, 1984, Houston, Texas. American Society of Civil Engineers, New York, I: 577-592

Shannon, C. E., Weaver, W (1949). The mathematical theory of communication. Univ. Illinois Press, Urbana

Simpson, J. J. (1983). Large-scale thermal anomalies in the California Current during the 1982-1983 El Niño. Geophys. Res. Lett. 10: 937-940

Simpson, J. J. (1984). El Niño-induced onshore transport in the California Current during 1982-1983. Geophys. Res. Lett. 11: $233-236$

Smith, P. E. (1985). A case history of an anti-El Niño El Niño transition on plankton and nekton distribution and abundances. In: Wooster, W S., Fluharty, D. L. (eds.) El Nin̄o north. Niño effects in the eastern Subarctic Pacific Ocean. Washington Sea Grant Program, Univ. Washington Seattle, p. 121-142

Sokal, R. R., Rohlf, F. J. (1981). Biometry. The principles and

This article was submitted to the editor practice of statistics in biological research, 2 nd edn. $\mathrm{W} \mathrm{H}$. Freeman and Co., San Francisco

Soto, R. (1985). Efectos del Fenómeno El Niño 1982-83 en ecosistemas de la I Region. Investigación pesq. 32: 199-206

Sousa, W. P., Schroeter, S. C., Gaines, S. D. (1981). Latitudinal variation in intertidal algal community structure: the influence of grazing and vegetative propagation. Oecologia (Berl.) 48: 297-307

Tegner, M. J., Dayton, P. K. (1987). El Niño effects on southern California kelp forest communities. Adv. ecol. Res. 17: 243-279

Tomicic, J. J. (1985). Efectos del fenómeno El Niño en las communidades litorales de la Península de Mejillones. Investigacion pesq. 32: 209-213

Wolfe, D. A., Champ, M. A., Flemer, D. A., Mearns, A. J. (1987). Long-term biological data sets: their role in research, monitoring, and management of estuarine and coastal marine systems. Estuaries 10: 181-193

Zar, J. H. (1984). Biostatistical analysis, 2nd edn. PrenticeHall, Inc. Englewood Cliffs, New Jersey

Zimmerman, R. C., Robertson, D. R. (1985). Effects of El Niño on local hydrography and growth of the giant kelp, Macrocystis pyrifera, at Santa Catalina Island, California. Limnol. Oceanogr. 30: 1298-1302

Manuscript first received: October 26, 1988

Revised version accepted: August 3, 1989 